\title{
Emergence of International and Local Clothing Brands in Bangladesh and Its Impact on Consumers
}

\author{
Abdul Baten ${ }^{1}$, Ahmed Ishtiaque ${ }^{2}$, Adib Sarwar ${ }^{3 *}$ \\ ${ }^{1}$ Assistant Professor, School of Business, University of Liberal Arts Bangladesh (ULAB), Dhaka, BANGLADESH \\ ${ }^{2}$ Assistant Professor, School of Business and Research Associate of Center for Enterprise Society, University of Liberal Arts Bangladesh \\ (ULAB), Dhaka, BANGLADESH \\ ${ }^{3}$ Research Associate, Center for Enterprise Society (CES), University of Liberal Arts Bangladesh (ULAB), Dhaka, BANGLADESH \\ "E-mail for correspondence: adib.sarwar@ulab.edu.bd
}

https://doi.org/10.18034/abr.v8i1.44

\begin{abstract}
The fashion industry has recently become one of the most fast growing industries in the capital city of Dhaka. Already there are several factories and outlets which are very popular with the consumers in Bangladesh. The quality of the products is not the only attraction for consumers to visit these stores. Creative concepts are also a reason which brings them to these outlets. There are Boutique outlets popping up in almost all major traffic areas throughout the city. In some top shopping malls single fashion boutique stores are available as well as factory outlets followed by branded stores. In most cases, these stores are largely dominated by global brands. Well-known foreign brands are available now in Bangladesh; some of which includes Gucci, Tommy Hilfiger, Ralph Lauren, Calvin Kline, Hugo Boss, Lacoste, Zara and many more. Social economic class in Dhaka is developing and because of that, global brands are becoming popular and affordable to the consumers. Globalization trend is increasing as well as advanced transportation and communication technology, which enables local customers to be exposed to and have access to various products and services from different countries. Studies found that customers often perceive foreign brands differently than local brands. Consumers in developed countries specifically have a preference in locally made products than foreign made products. On the other hand, in developing countries like Bangladesh, India, Pakistan etc. products from foreign countries are preferable than domestic products. The perception is that foreign clothing brands will impress others and increase the social status as they represent modern fashion and a sense of socio-economic class. In developing countries consumers have different expectations from different to global brands.
\end{abstract}

Key words: Creative Concepts, Consumer Behavior, Global Brands, Perceptions, Socio-economy Class, Globalization Trend, Advance Communication

\section{INTRODUCTION}

In 2016 Bangladesh has seen the growth in Gross Domestic Product (GDP) of $7.05 \%$ from the year before. In Bangladesh the average growth rate of GDP was $5.72 \%$ from 1994 until 2016, and 7.05\% was all-time high in 2016. There was a time when the Bangladeshi economy was heavily depended on agriculture, $85 \%$ of the people of our country were involved with agriculture. Currently, the situation has changed. Besides agriculture, readymade garments (RMG), bank and non-bank financial institutions, outsourcing, and foreign remittance from man power are adding

Extra value in the nation's economy. In 2014 industrial manufacturing contribution to our GDP was $17 \%$ whereas agricultural and wholesale-retail trade contributed each $13 \%$ of total $26 \%$. Besides economic, growth in Bangladesh increasing urbanization, changes in lifestyle, globalization and technological advancement in communication and transportation have changed in consumers' behavior. Now consumers have access to the internet, e-commerce sites and social media sites where they get exposed to a variety of products and services in the local and global market. Consumer attitudes and perceptions had changed since they have access to local and global brands. Like many other industries in Bangladesh, branding in the clothing industry reached a new peak. Consumers in developing countries like Bangladesh, India, and Pakistan and Sri-Lanka products choices are increasing from local and global brands especially for clothing. Both local and 
global clothing brands marketers need to understand the current competitive and challenging situation they also need to know consumers' decision-making process on products (Kearney, 2006). Research shows consumers prefer brands because of quality, comfortable to wear and reasonable price as well as emotional choices like social status, peer pressure and prestige (Batra et al., 2000). Like many developing countries Bangladeshi consumers also perceive the global brands are better than local brands. Previous findings also support, that local customers usually prefer foreign products and brands over local brands and products (Ahmed \& d'Astous, 1999). According to the literature review, there are two ways consumers get inspired by global brands, first one is quality products and the second one is prestige issue (Kwak, Juju, Larson, 2006).

\section{LITERATURE REVIEW}

According to The American Marketing Association (AMA) in the 1960s (Keller, 2001) 'brand' is "a name, term, sign, symbol, or design, or a combination of them, intended to identify the goods and services of one seller or group of sellers and differentiate them from those of competitors." Mariotti (1999) defines a brand as "a simplified 'shorthand' description of a package of value upon which consumers and prospective purchasers can rely to be consistently the same (or better) over long periods of time (Biplab, S. B., 1998). It distinguishes a product or service from competitive offerings". According to Kirmani \& Baumgartner (2000), brand's overall excellence depends on quality, durability, and customer satisfaction. On the other hand, brand name, warranty and after sale service are known as quality from consumers' perspective. Consumer Behavior towards Brands: Age, education, family size, gender, income, and race are demographic components are essential factors that influence consumer purchasing decision. In different age consumer behave differently. For example, a young consumer may behave differently than a middle age consumer. Previous research has found that females are more conservative and more patriotic than males, and females favor local products more than males (Han, 1988). Consumers show their unique characteristics when manufacturer display originality, unusual and exclusive products and brands. When manufacturer expresses their individuality, especially in accessories and clothing, it becomes well-known examples in those cases (Kron, 1983). Research indicates those consumers' values global brands over local brands and they also believe global brands are higher quality products and carry prestigious image (Nguyen, Barrett \& Miller 2005; Steenkamp, Batra \& Alden 2003). When the consumer tends to become loyal to a fixed brand is described as brand loyalty, and the consumer tends to purchase the brand over and over and don't want to switch to competitors' brands (Yoo, Donthu $\mathrm{N} \&$ Lee, 2000). A manufacturer has to create a position in consumer's mind, and promotion is the success element in this challenging marketing environment. In today's day, an age consumers are getting a broad range of commercial messages from different sources. Companies core value propositions should be communicated to their customers and what they communicate to them shouldn't be changed. Regarding communicating the value proposition to customers, it is seen that local brands are not as successful as global brands to reach at mass levels (Kotler, Armstrong, Agnihotri \& Haque, 2010). However, we have found that many local brands, which are also the more successful ones, are trying to focus on their value proposition in the market. For example, Yellow which is a subsidiary organization of Beximco Textile, a leading garments manufacturer, has also become a leading local brand and they are focusing on pure quality materials and upscale fashion. Others like Deshi Dosh are a group of 10 companies which produce clothes only focusing on local cultural designs. Customers wanting local designs for specific occasions are relying on the value preposition of these companies that they will always produce clothes focusing on local culture. Most shoppers emphasize on the quality or the brand which is important to them De Wulf et al. (2005). De Wulf et al. (2005) found that the brand equity is brand's power despite the familiarity, attractiveness, and goodwill, it has earned over time. These ultimately turns into higher sales and profit against competitor's brands. A study in branding by (Aaker, 1991); Kim and Chung, 1997; Hui and Zhou, 2003, Yasin and Noor, 2007) have found that quality, reputation, and popularity are major factors in measuring brand equity. In the international context marketing managers must identify the sources of brand equity and understand the importance of country it was made in measuring brand Pappu et al. (2006). Pappu et al. (2006) suggest that brand managers should observe and closely track brand's consumer-based equity for each product separately when a brand offer a variety of products. Assael (2004) describes the tendency to act on the object to being purchase behavior and on the other hand, Schiffman and Kanuk (2010), said there are stages of purchase behavior before purchasing decisions process. According to the theory of planned behavior proposed by Ajzen (1991), the behavior of interest can be used to predict by attitudes. Marketers always test the marketing mix that can influence buying behavior, such as testing the packing, advertising strategy, brand or product concepts Assael (2004). Marketers should measure consumer intention to purchase and determine what the factors that influence these intentions are. Consumers tend to have a positive attitude when they have a good experience of a product or service, so that helps to strengthen the customer relationship with the company (Assael, 2004).

\section{RESEARCH JUSTIFICATION}

The objective of this study is to determine the factors that change Bangladeshi consumer behavior in buying local and global brands. We wanted to compare the factors 
identified through literature and through this primary research in order to provide policy level recommendations which would be helpful for local brands to compete with their strong global competitors. In developing countries like Bangladesh consumers have different expectations from different brands and have the tendency to depend on brand as a sign to purchase by default. Currently, consumers in Bangladesh have various choices of foreign brands to choose from in the clothing industry and these products are perceived to be well known among target consumers.

According to our literature review we found age and income are some of the demographic components and these are essential factors that influence consumer purchasing decision. When it comes to age in our study we found that all age groups prefer local brands over international and customized brands. We found that with local brands, at all age groups the demand is $50 \%$ or above. For international brands demand is between $20 \%$ to $30 \%$, which gradually increases as the age goes up, but slightly dropping again when they are hitting 46 plus. Demand for customized clothing is going down as the age bracket goes up. Except when respondents are hitting 46 or above, the customized clothing demand seems to slightly go up again (25\%). In addition in our research we found as the level of income goes up the demand of international brands also goes up, but the change is from $28 \%$ to $30 \%$ and do not go up any higher than that.

Most shoppers emphasize on quality on brand which is important to them De Wulf et al. (2005). Our findings indicates that the customer profile from all socio economic classes are accepting the local brands more and more in the Bangladeshi market and it seems that they are willing to pay the price of international brands if the local brands can maintain the current level of quality standards and design as they are currently maintaining. There is a shift taking place in consumer behavior from international brands to local brands. From our research we found that local brands have penetrated the market to such an extent that they are not only competing with top international brands, but in many cases are leading in the market. The local brands are not only providing quality products, but are also providing competitive pricing for the target customers.

De Wulf et al. (2005) found that the brand equity is brand's power despite the familiarity, attractiveness and goodwill, it has earned over time. If we try to understand what brand equity means to the Bangladeshi consumers and why it is becoming more and more important these days we see that branded clothes, regardless of the product being an international or a local brand; it is considered as a very good gift which we can give to anyone from colleagues to friends to close family members. It is something that is well accepted by people from all walks of life. Not to mention that it is somewhat durable and very useful gift to give someone. Brands which are doing well in the market, the ones having a strong brand value are those which are up-to-date with the latest fashions, both eastern and western. It is very important to have the latest fashions and trends and maintain a certain quality standard for any brand to become successful in today's market. The authors believe that this research will give us a picture to what the Bangladeshi consumers are thinking when they are making their purchase decisions when it comes to clothing. Although the picture this research puts forth will bring up many new questions regarding consumer behavior of Bangladeshi shoppers; the study findings will still provide significant findings regarding behavior of the local market. This will not only provide a broad picture of the Bangladeshi local market where there is an almost non-existing literature on the topic under discussion; but the findings may also be helpful for companies in terms of making their business decisions regarding investments and expansion. The data may also be helpful for the government in terms of rethinking the current policies that guide this industry and make the Bangladeshi clothing industry ready for a more competitive global market.

\section{Methodology}

The researchers adopted the objective of this exploratory research to find the differences in perceptions and usage of clothing in Dhaka city, based on several demographic factors and some behavioral dimensions. The focus was to explore whether local brands can match up to global brands, as well as the perspective of delving into the dynamics of buyer behavior. Therefore, to conduct this research, a structured questionnaire was utilized as the tool to obtain results of various close-ended, categorical, Likert-scale type questions on the corresponding topic. The sampling technique assumed for the survey procedure was non-probabilistic convenience sampling through face-to-face interviews. The technique was considered to cater to the respondents from various demographics ranging between students and working professionals. Income categorization was also important in this research, as a supporting variable to other necessary demographics. The sample size selected for this research over four-hundred, specifically 414 respondents from all over Dhaka city. The location selected was the capital city Dhaka because this is where the main clothing production and manufacturing occurs, to complement all the foreign brands targeting the capital of Bangladesh as their point of origin for marketing.

For the analysis of the data from the survey, it was undertaken through two methods. For the understanding of the competition that local brands face with global brands, and the individual identity of the respondent when considering the customization of clothing, the analysis was presented in the basic descriptive form. Cross-tabulation of relevant variables highlighted our findings and was subsequently described through the 
subjective and qualitative understanding of the local scenario. For the collaboration of variables into groups of similar aspects, Factor Analysis was adapted.

A part of the questionnaire specifically catered to the behavioral aspect of the respondents. These behavioral questions attempted to discover the psychological phenomenon observed by respondents while considering using clothing regarding local, international, customized, economical, traditional, event-focused, competitivemarket, personal image, etc. It is obvious thereby that there are many dimensions of behavioral aspects to be measured. To condense these components, it was found convenient to conduct Principal Components Analysis, or in simpler terms Factor Analysis. The plot of these components was rotated upon an orthogonal axis (Varimax rotation), to extract into the most correlated factors. The components which shared the greatest correlation within a group were combined into one factor, and so on. Firstly, to check if this procedure is applicable, Kaiser-Meyer-Oklin Method of Sampling Adequacy was checked, which produced a measure of 0.661 . Additionally, Bartlett's Test of Sphericity yielded highly significant statistics, rejecting the null hypothesis that there was no correlation between variables in the population. Thus, the researchers progressed with conducting the analysis. To carefully guide through the correct application of the analysis, only communalities (factor variations with the common variance) of over 0.37 were retained. After the rotation, only those variables that had high factor loadings (which is the variable correlation with the factor) and the variables which did not load highly on to more than one factor were combined to produce a factor. Based on the values of higher than 1, which can be inspected from the Scree plot, four (4) factors have been extracted. These factors explained $52 \%$ of the total variation. Model fit was determined through examining the differences from the observed component correlations with the reproduced correlations which make up the residuals. Through inspection of these residuals, it was found that some of the residuals were over 0.15 in absolute value. However, the four (4) factors extracted, explained over half of the variation from over 18 variables and it was found to be acceptable to determine the behavioral aspects of the research on clothing.

\section{SURVEY FINDINGS}

The quantitative study is an attempt to better understand the trends in consumer behavior of the Bangladesh market. Although the data is limited to the capital city (Dhaka), the information is still relevant to the industry as the majority of the local and international brands of clothing are sold mostly in Dhaka.

The authors attempt to understand how the different demographic factors of the target respondents vary among the local international and customized brands of clothing. Looking into the overall income brackets of the respondents, quite surprisingly we find that there is not much variation when it comes to choice of brands regardless of what your income level is.

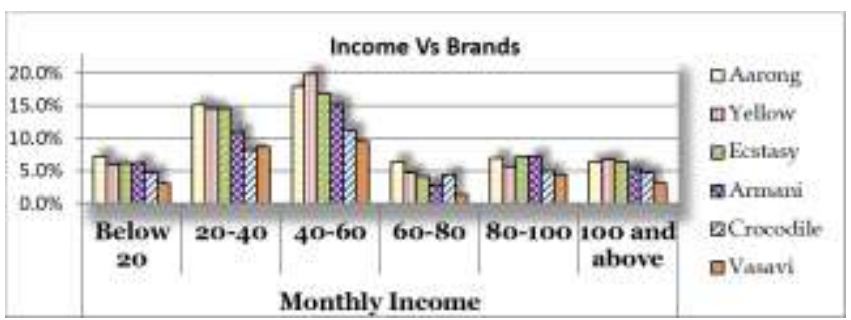

Figure 1: Income and Brand

At all income brackets we found that people are purchasing either Aarong or Yellow followed by Ecstasy, so those are the top three local brands in the market. They are followed by three international brands and again at every income brackets we find that their demand is first Armani then Crocodile followed by Vasavi. This indicates that local brands have penetrated the market to such an extent that they are not only competing with top international brands, but are leading in the market. The local brands are not only providing quality products, but are also providing competitive pricing for the target customer. Regardless of if you fall in the lower middle income, middle income or upper income brackets when it comes to branded clothes the choice is always local first. We find that when it comes to income the variation is in the purchase frequency. The richer you are the more frequently you will buy a brand of clothing and you top three choices will be a local brand instead of an international brand.

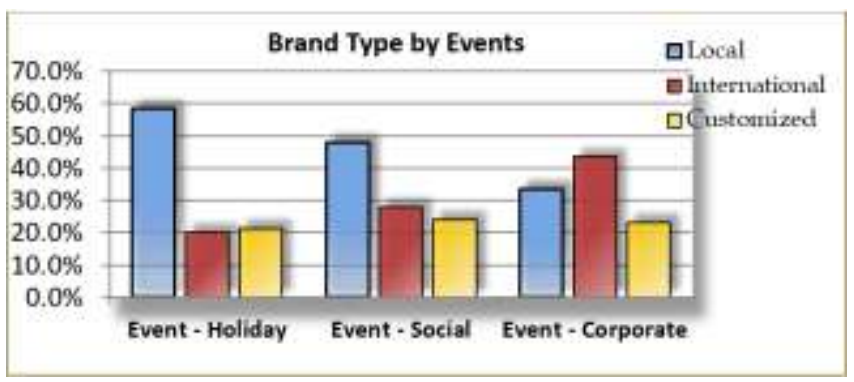

Figure 2: Brand Type and Events

We also present findings regarding choice of brands when it comes to attending various events such as Holidays, Social events or Professional Corporate events. In all three categories of events we find that roughly just above $20 \%$ of the respondents choose custom made clothing. Although it may be expected that custom-made local clothing should be the first choice during holidays and social events we find that in both categories the first choice of clothing is local brands (59\% \& 48\% respectively). Also in social events respondents prefer international brands over custom-made clothing ( $28 \%$ \& $24 \%$ respectively). Only in corporate events we find that international brands are mostly preferred, but in that category too we find that local brands are not that much far behind ( $44 \%$ \& $34 \%$ respectively). 


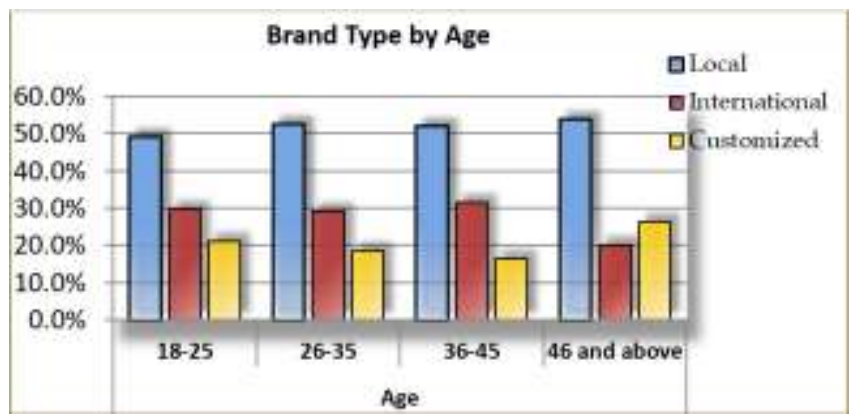

Figure 3: Brand Type and Age

When it comes to age demographics we find that all age groups prefer local brands over international brands and customized brands. This is a consistent finding with some Indian market consumers, who, despite age groups, prefer branded clothing (Ahmed \& Ravi, 2016; Laskar \& Abbas, 2014). We found that with local brands, at all age groups the demand is $50 \%$ or above. For international brands demand is between $20 \%$ to $30 \%$, which gradually increases as the age goes up, but slightly dropping again when they are hitting 46 plus. Demand for customized clothing is going down as the age bracket goes up. Except when respondents are hitting 46 or above, the customized clothing demand seems to slightly go up again (25\%).

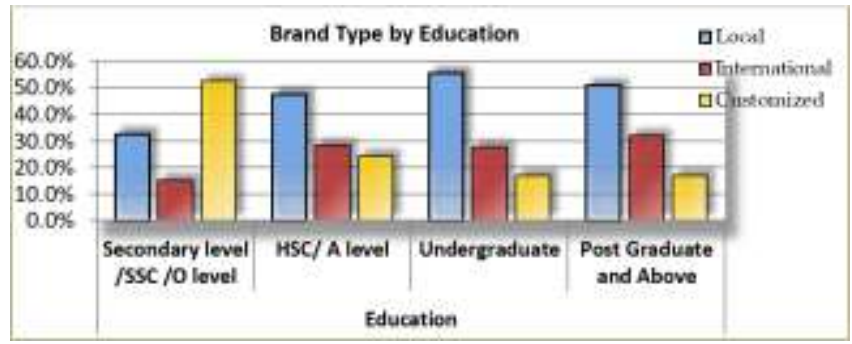

Figure 4: Brand Type and Education

If we take a closer look at the education level of the respondents' we find that students that fall in the SSC/O Level age group prefer to make customized cloths (just above $50 \%$ ) and this is justifiable when it comes to SSC students as they do not have much purchasing power at that age and are content with making customized clothes for themselves. We found that this demand drastically decreases with the increase in the level of education. This is a contradictory finding to the study on Indian males, where no significant relation between education levels and branded purchases were found (Ahmed \& Ravi, 2016). Quite the opposite is seen with the demand for purchasing of international cloths as we find that it gradually increases as the education level also increases. As people are more exposed to international brands at the higher level of education where someone may go abroad for higher education or study from case studies on international brands, it is natural that people with higher education level will be more exposed to international brands and hence would be more willing to purchase those brands. Again with the local brands we found that as the level of education goes up the demand for local clothes also goes up significantly compared to the other two categories of clothes. Demand for local brands basically dominate regardless of the level of education which indicated that people are gaining faith in the quality of local brands and are willing to pay decent amounts for Bangladeshi local brands of clothing.

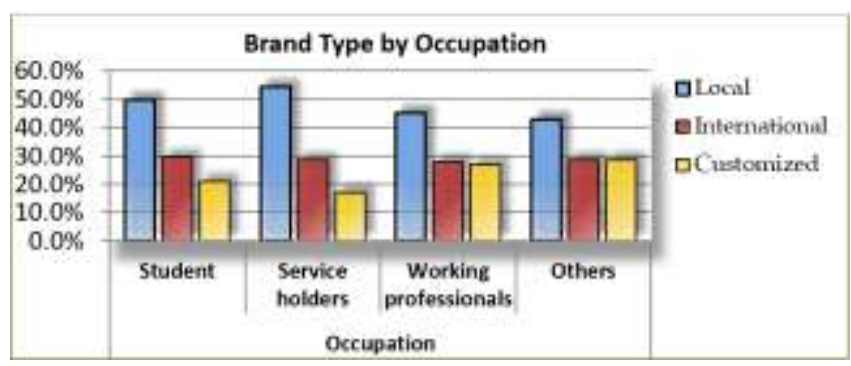

Figure 5: Brand Type and Occupation

Focusing on the occupation of the study respondents we find that students, service holders, working professionals and all others primarily prefer to purchase local brands (mostly between $42 \%$ to $52 \%$ ). But the international brands among all the categories remain just below $30 \%$. Also with customized cloths we find that service holders have the lowest demand for it (only about $18 \%$ ), students demand is only about $20 \%$ and for the other categories it is slightly higher which is about $28 \%$. Again regardless of what the occupation is we find that local brands dominate the Bangladesh clothing industry.

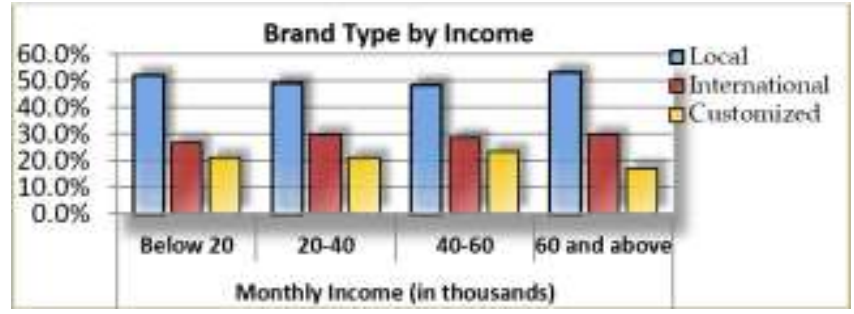

Figure 6: Brand Type and Income

As the level of income goes up the demand of international brands also goes up, but the change is from $28 \%$ to $30 \%$ and do not go up any higher than that. The demand for customized cloths on the other hand, remains quite stable at the $20 \%$ mark. The demand for local brands again dominates where the percentages go up to $50 \%$ and remains around that range regardless of the respondents' level of income going up. This is a positive indicator for the Bangladesh local clothing industry that people from all walks of life are relying of the quality of the local brands and their brand value and are willing to pay a decent price for locally established Bangladeshi brands.

The attitude towards Local brands are seen in a research outlining a combination of intricate sensitivities creating our preference towards either Local or Global brands. A demographic finding of older, ethnocentric people, harboring the values within a traditional culture, expresses a difference in general, consumer, and nationalcultural values, for local brands over global brands in 28 
countries (Steenkamp \& Martijn (2010). Parallely, consumers preferring to mix their choices between global and local brands are forward-looking women. These are additional insights which might complement our finding, that customized clothing are generally worn by groups who are older (aged 46 and above); an interesting hypothesis may be formed that this group might be women as well. The predominance of local "iconness" in consumers, builds a stronger brand value, which can positively compete against global brands (Özsomer, 2012). Our findings encompass higher priority over local brands irrespective of major demographic variations. The study cited however, found that demographic segmentation is on par with differentiated attitudes toward local brands in the presence of global brands, in the general industrial picture. Careful attention may be given to further research on minute demographic segmentation for local and global brands, specifically in the clothing industry of Bangladesh.

\section{FACTOR ANALYSIS}

This study has also conducted a principal component analysis on four (4) different factors which have shown to be significant in a Factor Analysis. The analysis has attempted to identify the various elements which have shown up in the survey.

The authors have to group these elements into four (4) overall factors which are:

- Brand Value of Clothing

- Affordability of Clothing

- Style of Clothing

- Customization of Clothing

\section{Brand Value of Clothing}

If we try to understand what brand value means to the Bangladeshi consumers and why it is becoming important these days, we see that branded clothes, regardless of it is an international brand or a good local brand, is considered as a very good gift to give anyone; either colleagues, friends or close family members. It is something that is well accepted by people from all walks of life. Not to mention that it is somewhat durable and very suitable gift to give someone. Brands which are doing well in the market and have a strong brand value are those who are up-to-date with the latest fashions, both eastern and western because it is very vital to have the latest fashion trends and maintain a certain quality standard for any brand to become successful in today's market. The role of brands is important in a person's life, since it also adds to quality to lifestyle. This is a finding in (Islam, M. \& Aktar, 2013), which also outlines that consumers are willing to pay extra for status, through branded clothing purchases. A similar study on females (Islam, Hossain, Rahman \&
Mostafizur, 2014) found strong proximity of fashion apparels from positive attitudes towards branded clothes and a feeling of self-respect. Further reasons why brands are increasing in priority is due to the mentality of the current customer demographic which suggests that the clothing you wear reflects the person's image not only in the workplace but also during social events. Our finding is supported by earlier research (Chowdhury \& Akter, 2018) which suggests men prefer "casual attire appropriate to occupation", not sacrifice clothing fit, since general consumers also highly valued clothes "complementing body type", representing the lack of sacrifice for self-image. Celebrities and, to some extent, friends and family have an influence on the type of cloth young consumers wear, a further evidence that a representable self is important for social gatherings

Table 1: Rotated Component Matrix from Factor Analysis

\begin{tabular}{|c|c|c|c|c|}
\hline & \multicolumn{4}{|c|}{ Components } \\
\hline & $\begin{array}{l}\text { Brand Value } \\
\text { of Clothing }\end{array}$ & $\begin{array}{l}\text { Aftoedable } \\
\text { Clothing }\end{array}$ & $\begin{array}{l}\text { Style of } \\
\text { Clothing }\end{array}$ & $\begin{array}{l}\text { Customization } \\
\text { of Clothing }\end{array}$ \\
\hline Branded clothes as gifts & .716 & & & \\
\hline Updated with faishion & .700 & & & \\
\hline $\begin{array}{l}\text { Clothing roflects image in } \\
\text { workplace and soxiety }\end{array}$ & 696 & & & \\
\hline Branded clothing is attordable & & -677 & & \\
\hline $\begin{array}{l}\text { Profer ethnic clothes for country'n } \\
\text { culture and pride }\end{array}$ & & .640 & & \\
\hline Economical preference on clothing & & 491 & & \\
\hline Westem clothes are convenient & & & 695 & \\
\hline $\begin{array}{l}\text { Intemational branda have better } \\
\text { quality } \& \text { design }\end{array}$ & & & 503 & \\
\hline $\begin{array}{l}\text { Westem clothing gives a modern } \\
\text { image }\end{array}$ & & & 535 & \\
\hline $\begin{array}{l}\text { Traditional clothing - only in } \\
\text { special occasions }\end{array}$ & & & & -719 \\
\hline $\begin{array}{l}\text { Customize dothes with chosen } \\
\text { fabrics }\end{array}$ & & & & 6377 \\
\hline
\end{tabular}

Extraction Method: Principal Component Analysis. Rotation Method: Varimax with Kaiser Normalization. Rotation converged in 6 iterations.

\section{Affordability of Clothing}

Although identified through the analysis that the Bangladeshi customers do not see branded clothes as affordable, it is particularly true for international brands. However, some local brands are becoming more and more affordable as new competitors are entering the open and growing market every day. It was also found that income levels do not determine if a person will buy a local brand, an international brand, or just go for a non-brand product. It seems that customers from all income brackets go for branded clothes and more for the local branded clothes. Maybe the only difference due to income could be the frequency of purchase and not the brand. Price insensitivity, in that, it is not the most important determinant, was also found in clothing purchases, specifically branded clothing. The significant relation coupled by the finding that there is an attitude of consumers to pay any price for branded clothes (Islam, M. \& Aktar, 2013). However, customers, in general, do want 
to market, specially the local brand cloths market to become more competitive so that the prices go done. Many customers also want to purchase ethnic clothes or local designs which they want to wear during certain cultural occasions. Some prefer purchasing local brands because it is a matter of pride that they are buying something local and it is just as fashionable and quality product as that of any western brands. Therefore, the affordability of local brands is a growing issue for the Bangladeshi markets because they consumers want more competing products to drive down the overall prices.

\section{Style of Clothing}

The overall style and design of the clothing are becoming important for the growing Bangladeshi market. Young consumers are seen to prioritize comfort in their clothing, typically preferring medium to light-weight fabric due to the weather patterns of the Bangladeshi region. Quality for t-shirts and popular denim pants are top-ranked for young clothing (Nurunnobi, Prasad, \& Arifuzzaman, 2016). Focusing on convenience, 'easy to wear' was an essential attribute for young males and females, carefully considering that clothing worn, 'complements their body type' (Chowdhury \& Akter, 2018). It is a threatening consideration when these findings are combined with a general perception in the local market that western clothes are much more convenient to wear and have a modern image and international brands are usually better in quality and design (Nguyen, Barrett \& Miller 2005; Steenkamp, Batra \& Alden 2003). However, these perceptions are changing every day as more and more local brands are entering the market and increasing the competition which in turn is improving local designs and bringing them up to the international standards. Also, Bangladesh becoming one of the leading garment manufacturers in the international market helps the local consumers to have more faith in the local brands' quality and style.

\section{Customization of Clothing}

Customized clothes are always in demand in the Bangladesh market, especially using chosen fabrics. Also, traditional clothing is not only used for special occasions anymore but nowadays used for any occasion. In many cases, the use of customized clothes is also cheaper and preferred by the younger generation (students). The attitude is understandable as the younger age groups usually have less purchasing power and prefer to customize their clothes which is cheaper than any brands and also keeps up with the latest fashions. Given that young people are likely to spend more on clothes (Mckinsay Quarterly, 2014), they also demonstrate interest in apparel purchases in other cases where they possess earning capabilities. This is complementary to our suggestion of cheaper preference of customized clothing. Young age groups of both genders in Bangladesh have been studied to prefer designed, casual clothing, a lifestyle choice which is termed "attractive" under theoretical constructs (Chowdhury \& Akter, 2018). In a study of Bangladeshi local brands on young University students, however, different findings report that a no-brand preference was found for knit and woven items (Prasad, Jannat, \& Ali, 2016). The rationale of a no-brand preference in the paper was the higher affordability of non-brands, corresponding to our suggestion of cheaper clothing prioritized by students, who are likely to be continuing education.

\section{Discussion}

According to the literature review, those consumers' who value global brands over local brands, and they also believe global brands are higher quality products. (Nguyen, Barrett \& Miller, 2005); Steenkamp, Batra \& Alden (2003). On the other hand, our findings indicate that the customer profile from all socio-economic classes is accepting the local brands increasingly in the Bangladeshi market. It seems that consumers are willing to pay the price of international brands if the local brands can maintain the current level of quality standards and design as they are currently maintaining. There is a shift taking place in consumer behavior from international brands to local brands. From our research, we found that local brands have penetrated the market to such an extent that they are not only competing with top international brands, but are leading in the market. The local brands are not only providing quality products, but are also providing competitive pricing for the target customers. Offering casual attires at discounted prices seems to be a winning proposition from earlier research finding as well (Chowdhury \& Akter, 2018; Chakrapani, 2015). It is encouraging that the overall demand for local brands have grown over the years as we have various established local brands operating in the market for over a decade now which are attracting local customers with their exclusive sales outlets, for example, Aarong, Yellow, Westecs, Estacy etc. The demand for local brands dominates where the percentages go up to $50 \%$ and remain around that range regardless of the respondents' level of income going up. This is a positive indicator for the Bangladesh local clothing industry that people from all walks of life are relying on the quality of the local brands and their brand value and are willing to pay a decent price for locally established Bangladeshi brands. De Wulf et al. (2005). De Wulf et al. (2005) found that the brand equity is brand's power despite the familiarity, attractiveness, and image, it has earned over time. To capture the consumer mindset of our local brand equity, local businesses ought to mostly focus on the cultural context. Businesses are to position themselves in such a way so as to reap the benefits of demographic and ethnographic scene of the country Steenkamp \& Martijn (2010); Özsomer (2012) which international brands will always be second-in-line to grasp. 
In our study, we found another reason why brands are becoming more and more important as the mentality of the current customer demographic suggests that the clothing you wear reflects the person's image not only in the workplace but also during social events.

\section{CONCLUSION}

As indicated from this study, the purchase behavior of the consumers living in Dhaka city, regardless of their demographic variance, seem to be favoring the growing clothing industry and their continuously improving local brands. At every age bracket, the demand for the local brands is also increasing. People are more inclined to buying from exclusive outlets of local brands, particularly those which have been around for a while and have established a brand value in the market with their established standard of quality and modern designs focusing on the fusion between the West and the East. Whatever the category of occupation, the demand for the local clothing brands remain the highest, and the service holders seem to be the highest promoters of the local brands followed by the students. We find that with education, the demand for the international brands increase up as the level of education also goes up. Although this was expected from the local market, it was seen that the demand for the local brands also goes up as the customer demographics become more and more educated. Also, regardless of the level of income, the customers demographic seem to prefer the local brands over the international brands and even over customized clothes. Although demand for international brands remains stable (between $20 \%$ to $30 \%$ ), as the income goes up the overall demand of the local brands are at a much higher level (around 50\%) which indicates that people are purchasing local brands at a higher frequency than the international brands and customized clothing products.

However, to demonstrate the expansion of local brands with respect to international exposure in the Bangladeshi market, a Chinese study of market expansion has rallied the breakaway of small-firm clustered growth. The form of growth focused on cheap labor and materials, and globalization will eventually take over local brands' international competitive strategies (Wei, 2011). They overtly emphasize the local regional distribution of production capacities within, and service functionalities to be spread across borders in coastal cities for maximum restructuration and industrial development of the clothing industry of China. Expanding homegrown markets across borders have been identified as a successful branding strategy to cater to the nationalistic perspective of local consumers in Turkey, and Singapore (Özsomer, 2012). Further evidence that this strategy works for emerging markets only, caters to our study of the Bangladeshi apparel industry. For market expansion from the artisan's perspective, an Indian study have outlined the difficulties in assessing the borderline between designing innovations, which are Indian, with Western inspirations (Khaire, 2011). Risks pave the way in tilting over to either side eventually losing consumers, who are inclined to their own preference, dominated by slow cultural shifts in their local community as new international styles eventually creep in the younger generations. Conjectured earlier that innovative entrepreneurs of local India have an opportunity to transform the country's international context through local driven designs, with slow western subtleties in their pride offerings. Perhaps, the Bangladeshi clothing designers and local brands can slowly follow suite in expanding their collections in a somewhat similar fashion, since the sub-regional fraction goes through the same cultural transformation and rapid industry expansion of the branded clothing.

\section{REFERENCES}

Aaker, D.A. (1991). Managing brand equity: Capitalizing on the value of a brand Name. The Free Press and New York.

Assael, H. (2004). Consumer Behavior - A strategic approach. Boston: Houghton Mifflin.

Bangladesh GDP Growth Rate. (n.d.). Retrieved March 23, 2017, from TRADING ECONOMICS: http:/ / www.tradingeconomics.com/bangladesh/gdpgrowth 4. Biplab, S. B. (1998), Hand Book of Marketing Publishing House.

Chakrapani, A. (2015). Consumer behavior and preferences of Indian consumers towards apparel purchase in retail markets of India. Innovative Journal of Business and Management, 4(4), 94-100.

Chowdhury, T.A. \& Akter, T. (2018). Fashion attributes preferred by young Bangladeshi consumers while buying casual clothes: A multi-dimensional approach. Journal of Fashion Marketing and Management: An International Journal. Retrieved from https:/ / doi.org/10.1108/JFMM-02-2018-0018

De Wulf, K., Odekerken-Schr-der, G., Goedertier, F. \& Van Ossel, G. (2005). Consumer perceptions of store brands versus national brands. Journal of Consumer Marketing, Vol. 22 No. 4, 223-32.

Han, C. M. (1989). Country Image: Halo or Summary Construct. Journal of Marketing Research. 26 (M ay), 222-229.

Hawkins, D. I., Best, R. J., \& Coney, K. A. (2004). Consumer behavior - Building marketing strategy. New York: McGrawHill. Keller, K.L. (2001) Strategic Brand

Islam, F., Hossain, M., Rahman, M. \&. Mostafizur. M. (2014). Influence of Factors on Female Consumers' Fashion Apparel Buying Behavior in Bangladesh. Global Journal of Management and Business Research: E Marketing, 14(8). 49-56.

Islam, M. \& Aktar, S. (2013). Role of Brands on Consumer's Buying Behavior in Bangladesh: a Study on Fashion Cloth. European Journal of Business and Management, 5(12).

Khaire, M. (2011). The Indian Fashion Industry and Traditional Indian Crafts. The Business History Review. 85(2), 345-366.

Kirmani, A. and Baumgartner, H. (2000). Reference Points Used in Quality and Value Judgements. Marketing Letters.11 (4). 299-310. 
Kotler, P., Armstrong, G., Agnihotri, P.Y. \& Hague, E.U. (2010). Principles of Marketing: South Asian Perspective. 13th ed. Singapore: Pearson Education.

Kron, J.V. (1983). Home-Psych: The social psychology of home and decoration. NY: Potter.

Laskar, J. I., \& Abbas, H. (2014). Consumer Perception of Branded Garments in Indian Apparel Industry. Journal of Business Administration and Management Sciences Research, 3(6), 101105. Retrieved from athttp://www.apexjournal.org

Management: Prentice-Hall, Upper Saddle River, NJ.

McKinsey Quarterly (2014). Resource Revolution: Gathering Force. McKinsey and Company, New York, NY.

Nguyen, T., Barrett, N. \& Miller, K. (2005). Perceived Brand Globalness: Antecedents and Out-come - The Case of Vietnamese Consumers. Proceedings of the $34^{\text {th }}$ EMAC Conference (pp.24-27). Università Commerciale Luigi Bocconi, Milan, Italy.

Nurunnobi, Prasad, R.K., \& Arifuzzaman, M. (2016). Buying Behavior of Young Customers in Bangladesh - A Movement towards Investigation of Their Fashion Attributes. International Journal of Textile Science, 5(1), 19-24. doi: 10.5923/j.textile.20160501.03.

Özsomer, A. (2012). The Interplay between Global and Local Brands: A Closer Look at Perceived BrandGlobalness and Local Iconness. Journal of International Marketing, 20(2), 72-95.

Pappu, R., Quester, P.G. \& Cooksey, R.W. (2006). Consumerbased brand equity and country-of-origin relationships: some empirical evidence. European Journal of Marketing. Vol. 40 Nos 5/6, 696-717.

Prasad, R.K., Jannat, F. \& Ali, A. (2016). Brand Selection on Different Items - A Study for Investigation of Bangladeshi Young Customer Priority Level. Journal of Textile Science $\mathcal{E}$ Engineering, 6:276. doi: 10.4172/2165-8064.1000276

S., Ahmed, \& A., Ravi. (2016). A Study on Consumer Behaviour towards Branded Garments among Male Shoppers. International Journal of Business and Management Invention, 5(5), 45-49. Retrieved from http:/ / www.ijbmi.org/papers/Vol(5)5/version2/F050502045049.pdf

Shaikat, M. N. (n.d.). Current Economic Condition of Bangladesh. ORDNUR TEXTILE AND FINANCE. Retrieved March 23, 2017, from: http:/ / ordnur.com/economy/current-economiccondition-of-bangladesh/

Steenkamp, J.B. \& Martijn, G. (2010). A Global Investigation into the Constellation of Consumer Attitudes toward Global andLocal Products. Journal of Marketing, 74(6), 18-40.

Wei, Y. H. D. (2011). Beyond the GPN-New Regionalism divide in China: restructuring the clothing industry, remaking the Wenzhou model. Geografiska Annaler. Series B, Human Geography, 93 (3), 237-251.

Yoo, B., Donthu N. \& Lee S. (2000). An examination of selected marketing mix elements and brand equity. Journal of the Academy of Marketing Science. 28(2), 195-211.

$--0--$ 
Online Archive: https://abc.us.org/ojs/index.php/abr/issue/archive 